\title{
Hypercalcaemia due to hyperparathyroidism in a patient with chronic renal failure and renal carcinoma
}

\author{
J. J. SZWED, L. J. GOTT, R. E. LEMPKE, AND IN SOOK SEO \\ From the Departments of Medicine, Surgery, and Pathology, Clowes Research Laboratories, \\ Wishard Memorial Hospital, Indiana University Medical Center, Indianapolis, Indiana 46202, USA
}

SUMMARY A 65-year-old woman with a history of a left heminephrectomy for renal carcinoma developed hypercalcaemia 11 years after the operation. The same kidney was found to contain a recurrent renal carcinoma. After the radical nephrectomy of the left kidney, hypercalcaemia remitted but reappeared 11 months later. The right kidney was small but functioned at a level of creatinine clearance of 10-15 ml/min. Metastatic work-up was negative, and secondary causes of hypercalcaemia were excluded. A neck exploration revealed a parathyroid adenoma. With parathyroid resection the serum calcium declined to normal, and the risk of hypercalcaemic nephropathy in the remaining kidney was precluded.

Hypercalcaemia is a common manifestation of malignancy of numerous organs, including the kidney (Albright and Reifenstein, 1948; Connor et al., 1956; Plimpton and Gellhorn, 1956; Gold and Shnider, 1959; Lucas, 1960; David et al., 1963; Noenickx et al., 1962; Moses and Spencer, 1963; Samuelsson and Werner, 1963; Goldberg et al., 1964). Primary hyperparathyroidism is a relatively common disorder, usually benign, with a frequency of 1 case per 1000 persons per year. The most common manifestation of this disorder is hypercalcaemia (Thorn et al., 1977). The association of renal carcinoma and hyperparathyroidism in the same patient is uncommon and has rarely been diagnosed before the death of the patient (Bernstein et al., 1965; Salama et al., 1971; Nemoto et al., 1977).

This report describes a patient with chronic renal failure, who had had a total left nephrectomy for a recurrent renal carcinoma accompanied by hypercalcaemia and, 11 months later, was found to have recurrent hypercalcaemia. The recurrent hypercalcaemia was not due to recurrent renal carcinoma but rather to a parathyroid adenoma. After removal of a parathyroid adenoma the hypercalcaemia remitted.

Received for publication 5 September 1978

\section{Case report}

The patient is a woman who was found to have a carcinoma of the left kidney during evaluation of vaginal prolapse in 1965 at age 54. The physical examination was normal except for obvious vaginal prolapse. The full blood count, urine analysis, serum electrolytes, serum calcium and phosphate, and creatinine clearance were normal. She underwent segmental resection of the left kidney (Fig. 1). On microscopic examination the tumour was a renal carcinoma. There were no metastases nor was there evidence of local invasion. At the time of the operation the patient was described as being quite 'irritable' by several physicians. She was discharged from hospital and followed with yearly intravenous pyelograms.

In July 1976, 11 years after the first operation, she was found to have progressive dilatation and clubbing of upper pole calyces, and an angiogram (Fig. 2) showed a $7 \times 4 \times 5 \mathrm{~cm}$ tumour mass involving one-half to two-thirds of the upper pole of the left kidney. The right kidney appeared to be small but without gross tumour involvement. Investigation revealed that the haemoglobin was $12.0 \mathrm{~g} / \mathrm{dl}$, WBC $7.8 \times 10^{9} / 1$ with a normal differential. The urine was clear with pH 6.0 and SG 1.010; there were 10-20 $\mathrm{RBCs} / \mathrm{hpf}$, 5-10 WBCs/hpf, and no casts nor bacteria. Urine cultures were negative on three 


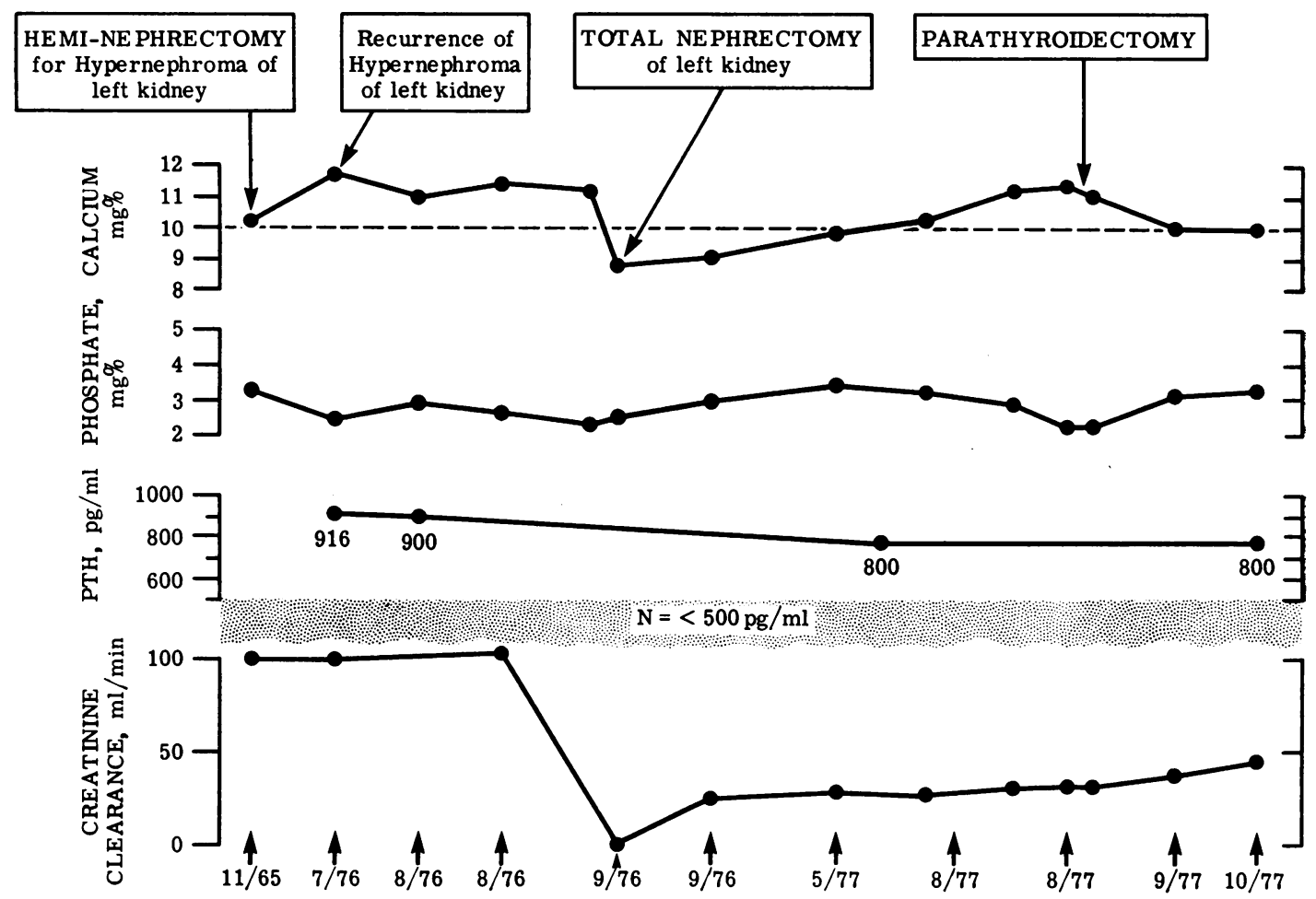

Fig. 1 A graph depicting the patient's course by following serum calcium, phosphate, PTH, and creatinine clearance.

separate occasions. Serum electrolytes were: sodium $135 \mathrm{mEq} / \mathrm{l}(135 \mathrm{mmol} / \mathrm{l})$, potassium $4 \cdot 1 \mathrm{mEq} / 1(4 \cdot 1$ $\mathrm{mmol} / \mathrm{l})$, chloride $99 \mathrm{mEq} / \mathrm{l}(99 \mathrm{mmol} / \mathrm{l})$, carbondioxide combining power $26 \mathrm{mEq} / 1(26 \mathrm{mmol} / \mathrm{l})$. Total serum proteins $6 \cdot 3 \mathrm{~g} / \mathrm{dl}(63 \mathrm{~g} / \mathrm{l})$ with albumin $3.6 \mathrm{~g} / \mathrm{dl}(36 \mathrm{~g} / \mathrm{l})$. Serum calcium levels of $11 \cdot 2 \mathrm{mg} / \mathrm{dl}$ $(2.8 \mathrm{mmol} / \mathrm{l}), 11.0 \mathrm{mg} / \mathrm{dl}(2.75 \mathrm{mmol} / \mathrm{l})$, and $11.5 \mathrm{mg} /$ dl $(2.88 \mathrm{mmol} / \mathrm{l})$ (normal range: $8 \cdot 4-10.0 \mathrm{mg} / \mathrm{dl}$; $2 \cdot 1-2 \cdot 5 \mathrm{mmol} / \mathrm{l}$ ) were found with corresponding serum phosphate levels of $3.2 \mathrm{mg} / \mathrm{dl}(1.03 \mathrm{mmol} / \mathrm{l}), 3.0 \mathrm{mg} /$ dl $(0.97 \mathrm{mmol} / \mathrm{l})$, and $2.8 \mathrm{mg} / \mathrm{dl}(0.90 \mathrm{mmol} / \mathrm{l})$. The ionised serum calcium was $2.54 \mathrm{mEq} / 1(1.27 \mathrm{mmol} / \mathrm{l})$ preoperatively, falling to $2 \cdot 22 \mathrm{mEq} / 1(1 \cdot 11 \mathrm{mmol} / \mathrm{l})$ postoperatively (normal range: $1 \cdot 78-2.28 \mathrm{mEq} / 1$; $0 \cdot 89-1 \cdot 14 \mathrm{mmol} / \mathrm{l}$ ), creatinine clearance was $100 \mathrm{ml} /$ min. All other laboratory or radiological investigations were normal.

The remainder of the left kidney was resected in September 1976 and found to contain a wellencapsulated neoplasm measuring $5.5 \times 6.0 \mathrm{~cm}$. On section it had a yellow, vascular cut surface with areas of haemorrhagic necrosis and microscopically was composed predominantly of polygonal clear cells (Fig. 3). No evidence of metastases was found at operation. The renal vessels and ureter were free of disease. Postoperatively the urine output ranged from 50 to $100 \mathrm{ml} /$ day for 48 hours and then rose to 1500 $\mathrm{ml} /$ day; creatinine clearance stabilised at $10-15 \mathrm{ml} /$ min during the next 10 days. The serum calcium level was $9.0 \mathrm{mg} / \mathrm{dl}(2.25 \mathrm{mmol} / \mathrm{l})$ and serum phosphate was $3.0 \mathrm{mg} / \mathrm{dl}(0.97 \mathrm{mmol} / \mathrm{l})$ at discharge in October 1976.

Before operation in 1976 the patient's parathyroid hormone level had been $916 \mathrm{pg} / \mathrm{ml}$. Postoperatively, the level declined to $800 \mathrm{pg} / \mathrm{ml}$ and has remained at approximately the same elevated level to the present time. While the patient's renal function gradually improved with hypertrophy of the remaining kidney, the serum calcium began to rise again and in August 1977 reached values of $10 \cdot 5-11 \cdot 5 \mathrm{mg} / \mathrm{dl}(2 \cdot 63-2 \cdot 88$ $\mathrm{mmol} / \mathrm{l})$; the ionised calcium was also elevated at $2.60 \mathrm{mEq} / \mathrm{l}(1.3 \mathrm{mmol} / \mathrm{l})$. Initially, the hypercalcaemia was thought to be due to the renal carcinoma, but the postoperative rise in 1977 suggested that the patient had a recurrence of tumour or had another, occult cause of hypercalcaemia. After another workup for metastatic neoplasm was found to be negative radiologically and biochemically, secondary causes of hypercalcaemia were evaluated. Bone marrow and serum protein electrophoresis were both normal and. 


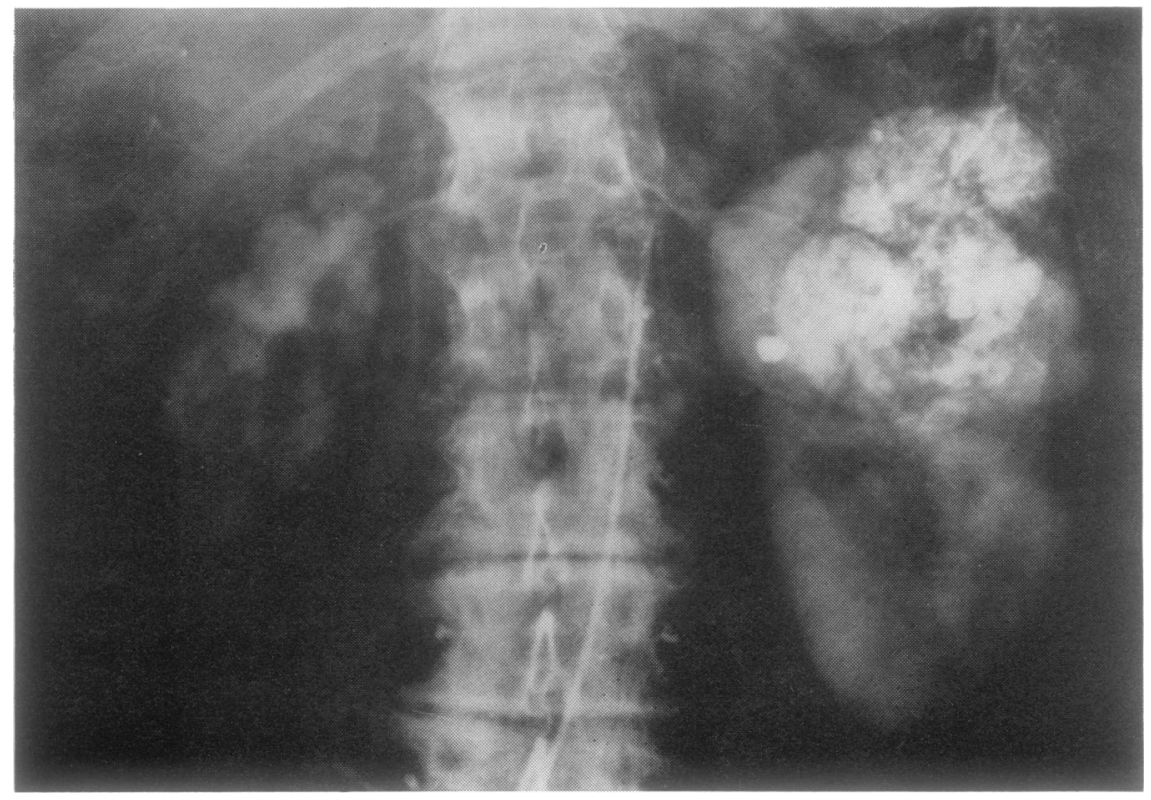

Fig. 2 Renal angiogram demonstrating large tumour of the left kidney and the small right kidney.

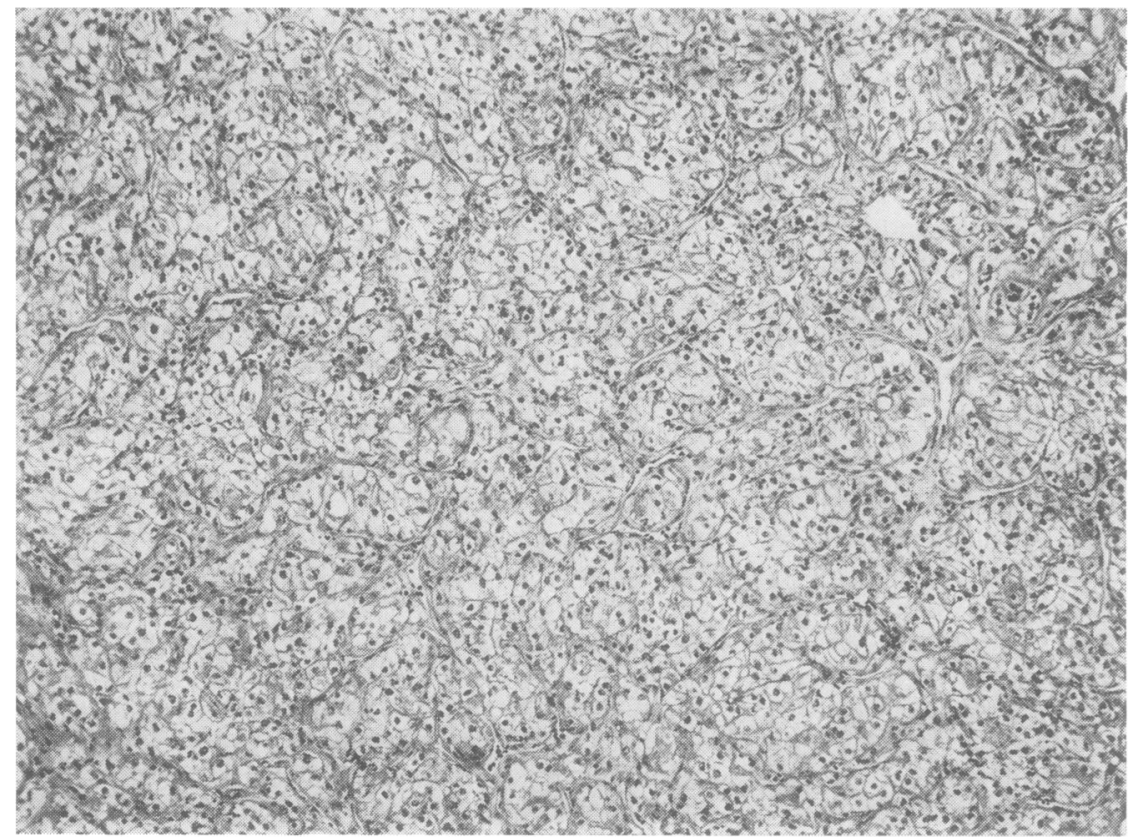

Fig. 3 Renal cell carcinoma showing typical clear cells with highly vascular stroma (Haematoxylin and eosin $\times 100$ ). 


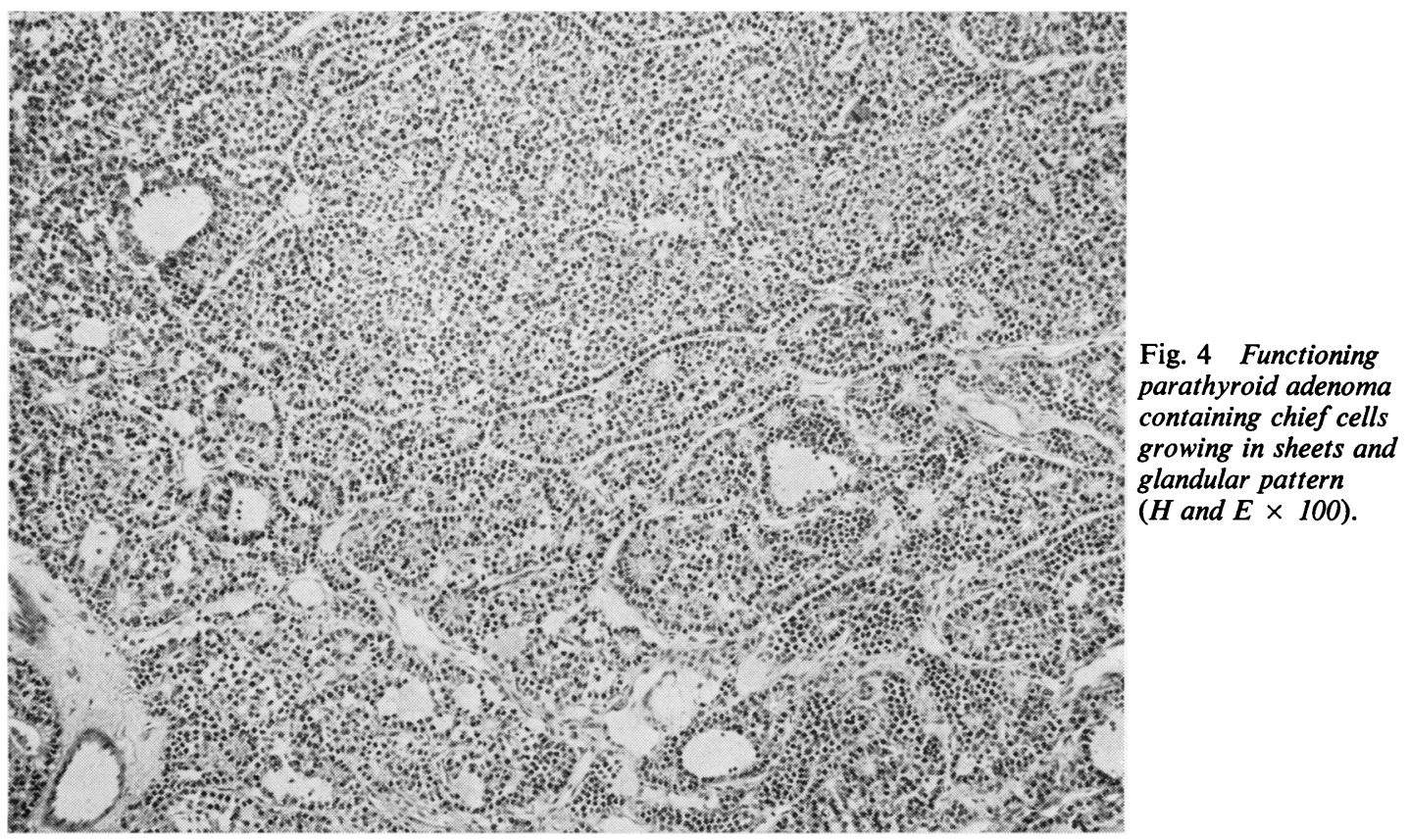

excluded the largest group of multiple myelomas, that is, secretory myelomas. Thyroid function studies were normal. Sarcoidosis was not suggested by either history, physical findings, or radiological examination. The patient was taking no vitamins nor diuretics, nor was she ingesting any milk products or antacids in large quantities to our knowledge. It was, therefore, concluded that a parathyroid adenoma might be present, although this diagnosis was supported only by the patient's chronic irritability, noted by many observers, and her hypercalcaemia.

Since the renal function was slowly improving with one kidney, it was decided to explore her neck for a possible parathyroid adenoma. While the level of serum calcium was not life-threatening, the residual kidney was at risk and its function could deteriorate if the hypercalcaemia persisted. At operation three parathyroid glands were identified. A mass removed from the right superior region of the thyroid gland measured $1.8 \times 1.0 \times 0.5 \mathrm{~cm}$ in its greatest dimensions. It had a thin, connective tissue capsule and a greyish-brown cut surface. Microscopically, it was an encapsulated lesion composed mainly of chief cells, which were growing in sheets and in a glandular pattern (Fig. 4). The adenoma was separated by a fibrous band from a definite rim of normal parathyroid. No mitosis was present. Three normal parathyroid glands were identified microscopically. The patient recovered uneventfully, and the serum calcium levels returned to the $9 \cdot 5-10 \cdot 0 \mathrm{mg} /$ dl $(2 \cdot 38-2.5 \mathrm{mmol} / \mathrm{l})$ range with a serum phosphate reading $3 \cdot 0-3.4 \mathrm{mg} / \mathrm{dl}(0 \cdot 97-1 \cdot 10 \mathrm{mmol} / \mathrm{l})$ two months after surgery. The patient now feels well, but her irritability persists. Her renal function continues to improve gradually and her creatinine clearance is now $45 \mathrm{ml} / \mathrm{min}$.

\section{Discussion}

The relationship between malignancy and increased parathyroid hormone (PTH) levels can be ascribed to the production of PTH by tumour tissue. The development of hypercalcaemia and hypophosphataemia in patients with malignant neoplasms has been reported. On the basis of histological studies, reasonably convincing evidence has been produced that a PTH-like substance can be formed in patients with tumours and hypercalcaemia (Kohout, 1966). In a series of 128 consecutive patients with malignant disease studied at necropsy, 34 had hypercalcaemia and all were found to have parathyroid hyperplasia on microscopic examination, with an increase in chief cells and eosinophilic cells. In 16 of the 34, the weight of the parathyroid glands was slightly above normal. Therefore, the relationship between parathyroid hyperplasia, PTH levels, and hypercalcaemia is such that true primary hyperparathyroidism can be mimicked by malignancy. 
In the Uppsala University Hospital study (Johansson and Werner, 1975), co-existing malignant disease was found in 13 of 350 patients with histologically proven parathyroid adenomas. The association, if any, between parathyroid disease and malignancy is unclear. However, they suggest three possible mechanisms for a direct relationship between hyperparathyroidism and malignancy.

First, the malignant process and 'primary' hyperparathyroidism might have a causative factor in common so that, for example, parathyroid tissue might be sensitive to a viral agent inducing myeloproliferative disease. There are no data to support this theory.

Secondly, the malignancy may cause hyperparathyroidism by a variety of possible mechanisms. For instance, the malignant cells may produce protein or proteins that directly stimulate the parathyroid gland, or bind the parathyroid hormone or block its effect, for example, on the kidney tubules. The protein might also bind serum calcium more or less specifically. It is interesting that such calciumbinding proteins have been identified (Lindgärde and Zettervall, 1973).

The third possibility is that primary hyperparathyroidism might cause malignancy, though there is no direct evidence to support such a theory. Clubb et al. (1964) reported a case in which a serum 'paraprotein' fraction disappeared after the removal of a hyperactive parathyroid adenoma, though they reported later that the paraprotein reappeared in the serum two and a half years after the operation. Furthermore, several cases of monoclonal IgG gammopathy associated with hyperparathyroidism have been reported (Dexter et al., 1972). Though hypercalcaemia disappeared in all three cases after parathyroidectomy, the monoclonal gammopathy persisted with no evidence of malignancy. No matter what the true pathophysiological interactions are among parathyroid disease, hypercalcaemia, and malignant disease, the implication remains that hypercalcaemia in patients with a malignancy should not be accepted as an inevitable sign of recurrent tumour.

In our patient with resected renal carcinoma and parathyroid adenoma, the situation was complicated by the fact that there was also chronic renal failure. Since this lowers total serum calcium levels, the parathyroid-induced hypercalcaemia failed to become apparent until postoperatively the renal function improved. The only symptom that the patient had for many years was 'irritability', and though this may be a clue to the duration of her hyperparathyroidism, it is impossible to ascertain whether parathyroid disease was present in 1965. Moreover, it is interesting that the irritability still persists. Eight months postparathyroidectomy the patient continues to do well. The creatinine clearrance is $45 \mathrm{ml} / \mathrm{min}$ and the serum calcium is normal.

\section{References}

Albright, F., and Reifenstein, E. C., Jr. (1948). The Parathyroid Glands and Metabolic Bone Disease. Williams and Wilkins, Baltimore.

Bernstein, D. S., Thorn, G. W., and Jackson, J. H. (1965). Hypercalcemia associated with sarcoidosis, hypernephroma and parathyroid adenoma: an unusual case with a nineteen-year follow-up. Journal of Clinical Endocrinology and Metabolism, 25, 1436-1440.

Clubb, J. S., Posen, S., and Neale, F. C. (1964). Disappearance of a serum paraprotein after parathyroidectomy. Archives of Internal Medicine, 114, 616-620.

Connor, T. B., Thomas, W. C., Jr., and Howard, J. E. (1956). The etiology of hypercalcemia associated with lung carcinoma (Abstract). Journal of Clinical Investigation, 35, 697-698.

David, N. H., Verner, J. V., and Engel, F. L. (1962).The diagnostic spectrum of hypercalcemia. Case report and discussion. American Journal of Medicine, 33, 88-110.

Dexter, R. N., Mullinax, F., Estep, H. L., and Williams, R. C., Jr. (1972). Monoclonal IgG gammopathy and hyperparathyroidism. Annals of Internal Medicine, 77, 759-764.

Gold, G. L., and Shnider, B. I. (1959). Some unusual syndromes associated with neoplastic disease. Annals of Internal Medicine, 51, 890-896.

Goldberg, M. F., Tashjian, A. J., Jr., Order, S. E., and Dammin, G. J. (1964). Renal adenocarcinoma containing a parathyroid hormone-like substance and associated with marked hypercalcemia. American Journal of Medicine, 36, 805-814.

Johansson, H., and Werner, I. (1975). Dysproteinemia, malignancy, and hyperparathyroidism. (Letter). Annals of Internal Medicine, 83, 121-122.

Kohout, E. (1966). Serum calcium levels and parathyroid glands in malignant disorders. Cancer, 19, 925-934.

Lindgärde, F., and Zettervall, O. (1973). Hypercalcemia and normal ionized serum calcium in a case of myelomatosis. Annals of Internal Medicine, 78, 396-399.

Lucas, P. F. (1960). Acute hypercalcaemia from carcinomatosis without bone metastasis. British Medical Journal, 1, 1330-1331.

Moses, A. M., and Spencer, H. (1963). Hypercalcemia in patients with malignant lymphoma. Annals of Internal Medicine, 59, 531-536.

Nemoto, R., Schimizu, S., Kuwahara, M., Harada, T., Kato, T., Takanaschi, R., and Tsuchida, S. (1977). Primary hyperparathyroidism with triple cancers consisting of renal cell carcinoma, nasopharynx carcinoma and thyroid carcinoma. Journal of Urology, 117, 369-370.

Noeninckx, F., Six, R., and Van Laethem, L. (1962). Tumeur maligne de l'ovaire a effet hypercalcemiant et phosphaturique. Acta Clinica Belgica, 17, 406-412.

Plimpton, C. H., and Gellhorn, A. (1956). Hypercalcemia 
in malignant disease without evidence of bone destruction. American Journal of Medicine, 21, 750-759.

Reiss, E., and Alexander, F. (1953). The tubular reabsorption of phosphate in the differential diagnosis of metabolic bone disease. Journal of Clinical Endocrinology and Metabolism, 19, 1212-1222.

Salama, F., Luke, R. G., and Hellebusch, A. A. (1971). Carcinoma of the kidney producing multiple hormones. Journal of Urology, 106, 820-822.

Samuelsson, S. M., and Werner, I. (1963). Hepatic carcinoma simulating hyperparathyroidism. Acta Medica Scandinavica, 173, 539-547.

Thorn, G. W., Adams, R. D., Braunwald, E., Isselbacher, K. J., and Petersdorf, R. G. eds. (1977). Harrison's Principles of Internal Medicine, 8th edition, pp. 20142022. McGraw-Hill, New York.

Requests for reprints to: Dr James J. Szwed, Wishard Memorial Hospital, Renal Section, OPW 439, 1001 West 10th Street, Indianapolis, Indiana 46202

\section{The February 1979 Issue}

\section{THE FEBRUARY 1979 ISSUE CONTAINS THE FOLLOWING PAPERS}

The priority test request form A. R. HENDERSON

An approach to quality and performance control in a computer-assisted clinical chemistry laboratory P. E. UNDRILL AND S. C. FRAZER

Urinary total porphyrins by ion exchange analysis: Reference values for the normal range and remarks on preformed porphyrins in acute porphyria urine J. FOGSTRUP AND T. $\mathrm{K}$. WITH

An interfering factor in the automated analysis of calcium P. GOSLING AND H. G. SAMMONS

Serum protein profile in sickle cell disease $U$. $P$. ISICHEI

Comparison of enzyme-linked immunosorbent assay (ELISA) technique and complement-fixation test for estimation of cytomegalovirus IgG antibody J. C. BOOTH, GILlian HANNINGTON, T. A. G. AZIZ, AND H. STERN

Comparison of passive haemagglutination and haemagglutination-inhibition techniques for detection of antibodies to rubella virus C. J. BIRCH, B. P. GLAUN, V. HUNT, L. G. IRVING, AND I. D. GUST

Hepatitis Be antigen and antibody in hepatitis $B$ surface antigen positive blood donors A. BARR, S. H. BLACK, C. J. BURRELL, B. DOW, AND I. MACVARISH

Rapid serotyping of groups $\mathrm{A}, \mathrm{B}$, and $\mathrm{C}$ meningococci by rocket-line immunoelectrophoresis and coagglutination D. DANIELSSON AND P. OLCÉN

Anaerobic organisms in postoperative wounds P. J. SANDERSON, M. W. D. WREN, AND A. W. F. BALDWIN

Effect of $\mathrm{pH}$ on sporicidal and microbicidal activity of buffered mixtures of alcohol and sodium hypochlorite JANET E. DEATH AND D. COATES
Anti blood group-M autoantibodies with livedo reticularis, Raynaud's phenomenon, and anaemia J. M. SANGSTER, M. G. KENWRIGHT, M. P. WALKER, AND A. C. PEMBROKE

Periodic acid-Schiff reaction and prognosis in lymphoblastic leukaemia J. S. LILLEYMAN, v. MILLS, P. J. SUGDEN, AND J. A. BRITTON

A rapid method for electron microscopic examination of blood cells ANTONIO COPPOLA

A comparison of thiomersal and $50 \%$ alcohol as preservatives in urinary cytology M. E. BEYER-BOON, P. W. ARENTZ, AND R. S. KIRK

Gastrin cells and fasting serum gastrin levels in duodenal ulcer patients JUAN PIRIS AND R. WHITEHEAD

Histological appearances of the gastric mucosa 15-27 years after partial gastrectomy ANN SAVAGE AND S. JONES

A new technique for Gram staining paraffinembedded tissue KRESTEN ENGBEK, KIRSTEN STEHR JOHANSEN, AND MERETE EGHOLM JENSEN

\section{Technical methods}

Storage of reagent platelets for anti-platelet antibody testing in the ${ }^{51} \mathrm{Cr}$ platelet lysis assay $\mathrm{G}$. $\mathrm{E}$. LIZAK AND F. C. GRUMET

Use of sheep erythrocytes as solid phase supports in double antibody immunoassay systems JOHN KANE AND ERIC GOWLAND

Demonstration of creatine phosphokinase in human myocardial slices R. J. TRICKEY AND M. J. DAVIES

Letter to the Editor

Book reviews

Copies are still available and may be obtained from the PUBLISHING MANAGER, BRITISH MEDICAL ASSOCIATION, TAVISTOCK SQUARE, LONDON WC1H 9JR, price $£ 3.00$, including postage 